\title{
The exploration of N6-deoxyadenosine methylation in mammalian genomes
}

\author{
Xuwen $\mathrm{Li}^{1}{ }^{\circledR}$, Zijian Zhang ${ }^{1}$ (]), Xinlong Luo ${ }^{1}$ (]), Jacob Schrier ${ }^{1}$, Andrew D. Yang ${ }^{1,2}$, Tao P. Wu ${ }^{1,3,4 \bowtie}$ \\ ${ }^{1}$ Department of Molecular and Human Genetics, Baylor College of Medicine, Houston, TX 77030, USA \\ 2 Medical Scientist Training Program, Baylor College of Medicine, Houston, TX 77030, USA \\ ${ }^{3}$ Huffington Center on Aging, Baylor College of Medicine, Houston, TX 77030, USA \\ ${ }^{4}$ Dan L Duncan Comprehensive Cancer Center, Baylor College of Medicine, Houston, TX 77030, USA \\ $\triangle$ Correspondence: tao.wu@bcm.edu (T. P. Wu) \\ Received March 3, 2021 Accepted July 12, 2021
}

\begin{abstract}
$N^{6}$-methyladenine $\left(N^{6}-m A, m^{6} d A\right.$, or $\left.6 m A\right)$, a prevalent DNA modification in prokaryotes, has recently been identified in higher eukaryotes, including mammals. Although $6 \mathrm{~mA}$ has been well-studied in prokaryotes, the function and regulatory mechanism of $6 \mathrm{~mA}$ in eukaryotes are still poorly understood. Recent studies indicate that $6 \mathrm{~mA}$ can serve as an epigenetic mark and play critical roles in various biological processes, from transposable-element suppression to environmental stress response. Here, we review the significant advances in methodology for $6 \mathrm{~mA}$ detection and major progress in understanding the regulation and function of this non-canonical DNA methylation in eukaryotes, predominantly mammals.
\end{abstract}

KEYWORDS DNA N ${ }^{6}$-methyladenine $(6 \mathrm{~mA})$, mammalian DNA modification, non-canonical mammalian DNA methylation

\section{INTRODUCTION}

DNA methylation is a biological process by which the methyl group is covalently added to the DNA base. DNA methylation has been shown to play essential roles in numerous biological processes and human diseases, including gene expression regulation, chromatin organization, tumorigenesis, and neurodegeneration (Smith and Meissner 2013; Schübeler 2015; Luo et al. 2018a). Although several forms of DNA methylation, such as $\mathrm{N}^{4}$-methylcytosine $(4 \mathrm{mC})$, 5 -methylcytosine $(5 \mathrm{mC})$, and $\mathrm{N}^{6}$-methyladenine $(6 \mathrm{~mA})$, have been observed in prokaryotes and unicellular eukaryotes (Gorovsky et al. 1973; Bromberg et al. 1982; Sánchez-
Romero et al. 2015), 5mC and its oxidation derivatives (5hydroxymethylcytosine $/ 5 \mathrm{hmC}, 5$-formylcytosine $/ 5 \mathrm{fC}$, and 5-carboxylcytosine/5caC) were considered as the only forms of DNA epigenetic modifications in mammals ( $\mathrm{Li}$ and Zhang 2014). After decades of exploration, recent studies have identified the presence of DNA $6 \mathrm{~mA}$ in multiple species of eukaryotes, including mammals (Fu et al. 2015; Greer et al. 2015; Zhang et al. 2015; Wu et al. 2016). In prokaryotes, one of the most well-known functions of $6 \mathrm{~mA}$ is to help the host recognize exogenous DNA and to protect endogenous DNA from restriction endonuclease (REase) cleavage (Marinus and Morris 1973, 1974). While the existence and biological function of $6 \mathrm{~mA}$ in mammals have yet to be fully determined, several studies have provided convincing evidence for the presence of functional $6 \mathrm{~mA}$ in the mammalian genomes (Wu et al. 2016; Xie et al. 2018; Hao et al. 2020; Zhang et al. 2020a; Li et al. 2020b). In this review, we will discuss recent advances in novel approaches for DNA $6 \mathrm{~mA}$ detection in the eukaryotic genomes, the current understanding of the regulatory pathways involved in the deposition, recognition, and removal of $6 \mathrm{~mA}$, and the recent progress in understanding the biological function of $6 \mathrm{~mA}$ in eukaryotes, predominantly mammals.

\section{BRIEF INTRODUCTION OF 6mA IN PROKARYOTES}

The $6 \mathrm{~mA}$ was first discovered in Bacterium coli by Dunn et al. in the 1950s (Dunn and Smith 1955, 1958). Subsequent studies revealed $6 \mathrm{~mA}$ as a widespread presence throughout bacterial genomic DNAs (Vanyushin et al. 1968). DNA 6mA was shown to play a critical role in the restrictionmodification (R-M) system (Boyer 1971; Smith et al. 1972; Marinus and Morris 1973), in which unmodified foreign DNA can be recognized and cleaved by REase, whereas the host 
genome is methylated and protected by its $6 \mathrm{~mA}$ methyltransferase (MTase). However, these studies also revealed that only a small portion of $6 \mathrm{~mA}$ is involved in R-M systems in $E$. coli, and the function for the majority of $6 \mathrm{~mA}$ in $E$. coli remained elusive until the discovery of dam MTase. Marinus et al. observed an $84 \%$ reduction of $6 \mathrm{~mA}$ levels in an $E$. coli strain with dam-3 mutation, indicating dam-3 as the gene that encodes the MTase responsible for a major portion of $\mathrm{N}^{6}$-adenine methylation in E. coli (Marinus and Morris 1974). Further investigation revealed that the dam-3 mutant strain is more sensitive to UV irradiation and mitomycin C treatment. DNA isolated from dam-3 mutant strains contains more single-stranded breaks, suggesting the protective effect of $6 \mathrm{~mA}$ on DNA strand breaks(Marinus and Morris 1974). 6mA has also been shown to play critical roles in DNA replication initiation (Lu et al. 1994), DNA mismatch repair (Kramer et al. 1984), and gene expression regulation (Sternberg 1985; Robbins-Manke et al. 2005). Further studies are required to investigate whether these $6 \mathrm{~mA}$ functions observed in prokaryotes are conserved in eukaryotes.

\section{THE DISCOVERY OF 6mA IN EUKARYOTES}

In addition to prokaryotes, $6 \mathrm{~mA}$ has been also identified as one of the primary DNA modifications in many unicellular eukaryotes for decades, such as Tetrahymena thermophila and Tetrahymena pyriformis (Gorovsky et al. 1973; Bromberg et al. 1982). Yet, the identification of $6 \mathrm{~mA}$ in metazoan had been unsuccessful until recently due to the limitation of detection approaches and lack of specific model systems. With the significant advances in ultra-high-performance liquid chromatography coupled with triple-quadrupole tandem mass spectrometry (UHPLC-MS/MS) and third-generation single-molecule real-time sequencing (SMRT-seq), 6mA was detected in Chlamydomonas (Fu et al. 2015), C. elegans (Greer et al. 2015), and Drosophila (Zhang et al. 2015). In 2016 , the presence of $6 \mathrm{~mA}$, for the first time, was reported in mammalian genomes including mouse embryonic stem cells (mESCs) (Wu et al. 2016) and mouse kidney (Koziol et al. 2016). Later on, 6mA was reported in mouse brain (Yao et al. 2017; Li et al. 2019b), pig embryo (Liu et al. 2016), and the human genome (Xie et al. 2018; Xiao et al. 2018) (Table 1).

\section{THE METHODS TO DETECT 6mA IN EUKARYOTES}

In addition to UHPLC-MS/MS and SMRT-seq mentioned above, several other detection methods, such as antibodybased DNA immunoblotting, immunofluorescence staining, and sequencing, have been utilized to detect, locate, and quantify $6 \mathrm{~mA}$ in multicellular eukaryotes. However, $6 \mathrm{~mA}$ 's abundance was shown to be extremely low in most mammalian tissues or cell lines, making the detection and evaluation of mammalian $6 \mathrm{~mA}$ a challenging endeavor. Here, we summarize the current methods used in detecting $6 \mathrm{~mA}$ in eukaryotes and emerging approaches that may be adopted to further investigate the genomic distribution of $6 \mathrm{~mA}$ (Table 2).

\section{Mass spectrometry-based methods}

Mass spectrometry, a powerful analytical technique, has been widely used to accurately quantify known compounds of biological samples. The ultra-high sensitivity (on the order of $0.00001 \%$ ) makes mass spectrometry practical for detecting the low abundant $6 \mathrm{~mA}$ in mammalian DNA. Besides, liquid chromatography (LC) or high-performance liquid chromatography (HPLC) can be used to separate DNA $6 \mathrm{~mA}$ from RNA N6-methyladenosine $\left(\mathrm{m}^{6} \mathrm{~A}\right)$, other nucleotides, and other DNA modifications. Thus, liquid chromatography coupled with mass spectrometry (LC-MS/MS) provides an ideal method to reliably detect the low abundant $6 \mathrm{~mA}$ in the mammalian genome (Huang et al. 2015; Liu et al. 2017).

Before conducting LC-MS/MS to determine the abundance of $6 \mathrm{~mA}$, genomic DNA extracted from cells or tissues need to be enzymatically hydrolyzed to mononucleotides. It was suggested that the commercial enzymes used to hydrolyze DNA can be contaminated by bacterial nucleotides, resulting in an overestimation of $6 \mathrm{~mA}$ level in eukaryotic genomes by LC-MS/MS (O'Brown et al. 2019). However, a more recent LC-MS/MS experiment has determined that the suspected contamination is below $0.1 \mathrm{ppm}$ or detection limits, while the $6 \mathrm{~mA}$ ranges from 7 in embryonic stem cells to $120 \mathrm{ppm}$ in developing trophoblast stem cells in murine ( $\mathrm{Li}$ et al. 2020b). Thus, with proper controls, LC-MS/MS remains a reliable approach to quantify the abundance of $6 \mathrm{~mA}$. Recently, one method developed by Dr. Hailin Wang's lab introduced a metabolic labeling approach for accurate detection of $6 \mathrm{~mA}$ and eliminating most false positive signals (Liu et al. 2017).

Although the mass spectrometry-based methods can accurately quantify the low abundance of $6 \mathrm{~mA}$, it requires protocol development and optimization to achieve adequate specificity and sensitivity, which is often challenging and time-consuming (Wetzel and Limbach 2016). For instance, studies reported that $6 \mathrm{~mA}$ in $\mathrm{mESCs}$ and human pluripotent stem cells (hPSCs) is below the detection limit of their LCMS/MS methods (Ratel et al. 2006; Schiffers et al. 2017; Abakir et al. 2020). By contrast, Li et al. reported a high $6 \mathrm{~mA}$ level (>1000 ppm) in human embryonic stem cells (hESCs), human mesenchymal stem cells (hMSCs), and human vascular smooth muscle cells (hVSMCs) in their LC-MS/MS experiments (Li et al. 2020a). Additionally, a lower level of $6 \mathrm{~mA}$ was detected by dot blotting in mESCs cultured under traditional $2 \mathrm{i}$ condition (ERK and GSK3b inhibitors, the culture condition used by Schiffers et al.) than those cultured in serum and LIF condition ( $\mathrm{Li}$ et al. 2020b). In a separate study, Liu et al. reported that a similar level of $6 \mathrm{~mA}$ was detected by LC-MS/MS in mESCs cultured in $2 \mathrm{i}$ condition or serum and LIF condition (Liu et al. 2021), and that $6 \mathrm{~mA}$ level in their mESCs is around $0.4-0.8$ ppm, which is ten-fold 


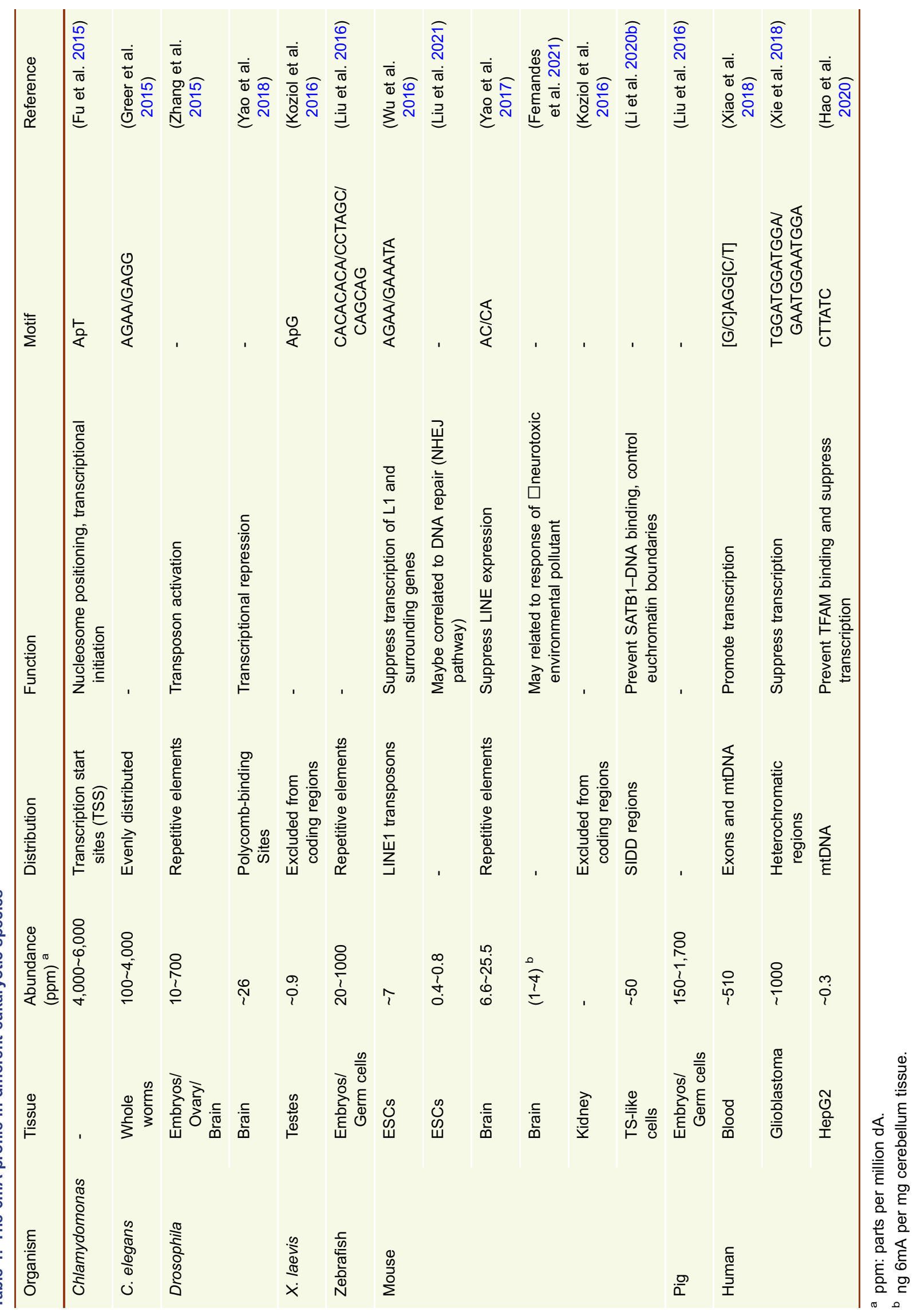


Table 2. Summary of the methods in detecting $6 \mathrm{~mA}$ in eukaryotes

\begin{tabular}{|c|c|c|c|c|c|}
\hline Methods & Application & Advantages & Disadvantages & $\begin{array}{l}\text { Antibody } \\
\text { dependent }\end{array}$ & References \\
\hline UPLC-MS/MS & $\begin{array}{l}\text { Abundance } \\
\text { quantification }\end{array}$ & $\begin{array}{l}\text { Ultra-high } \\
\text { sensitivity }\end{array}$ & $\begin{array}{l}\text { No sequence } \\
\text { information, high } \\
\text { operational cost }\end{array}$ & No & $\begin{array}{l}\text { (Huang et al. 2015; } \\
\text { Liu et al. 2017) }\end{array}$ \\
\hline Immunoblotting & $\begin{array}{l}\text { Abundance } \\
\text { quantification }\end{array}$ & Easy to apply & Semi-quantitative & Yes & (Stott 1989) \\
\hline Immunofluorescence & $\begin{array}{l}\text { Subcellular } \\
\text { localization }\end{array}$ & $\begin{array}{l}\text { Multiple staining; } \\
\text { heterogeneity } \\
\text { detection }\end{array}$ & Semi-quantitative & Yes & (Im et al. 2019) \\
\hline 6mA-DIP-seq & $\begin{array}{l}\text { Genomic } \\
\text { localization }\end{array}$ & $\begin{array}{l}\text { Whole-genome } \\
\text { mapping }\end{array}$ & Low resolution & Yes & $\begin{array}{l}\text { (Greer et al. 2015; } \\
\text { Zhang et al. 2015; } \\
\text { Wu et al. 2016) }\end{array}$ \\
\hline 6mA-CLIP-exo-seq & $\begin{array}{l}\text { Genomic } \\
\text { localization }\end{array}$ & $\begin{array}{l}\text { Higher-resolution } \\
\text { compared to } \\
\text { DIP-seq }\end{array}$ & $\begin{array}{l}\text { More complicated } \\
\text { workflow }\end{array}$ & Yes & (Fu et al. 2015) \\
\hline DA-6mA-seq & $\begin{array}{l}\text { Genomic } \\
\text { localization }\end{array}$ & $\begin{array}{l}\text { Single base } \\
\text { resolution }\end{array}$ & Motif dependent & No & (Luo et al. 2016) \\
\hline SMRT sequencing & $\begin{array}{l}\text { Genomic } \\
\text { localization }\end{array}$ & $\begin{array}{l}\text { Single base } \\
\text { resolution }\end{array}$ & $\begin{array}{l}\text { High false-positive } \\
\text { rate when } 6 \mathrm{~mA} \\
\text { level is ultra-low }\end{array}$ & No & (Flusberg et al. 2010) \\
\hline $\begin{array}{l}\text { Oxford Nanopore } \\
\text { sequencing }\end{array}$ & $\begin{array}{l}\text { Genomic } \\
\text { localization }\end{array}$ & $\begin{array}{l}\text { Single base } \\
\text { resolution }\end{array}$ & $\begin{array}{l}\text { High false-positive } \\
\text { rate }\end{array}$ & No & (Rand et al. 2017) \\
\hline $\begin{array}{l}\mathrm{Ag}^{+} \text {mediated } \\
\text { replication }\end{array}$ & Oligonucleotides & High specificity & $\begin{array}{l}\text { Only applicable to } \\
\text { known } 6 \mathrm{~mA} \text { sites }\end{array}$ & No & (Hong et al. 2016) \\
\hline $\begin{array}{l}6 \mathrm{~mA} \text { covalent } \\
\text { functionalization }\end{array}$ & $\begin{array}{l}\text { Genomic } \\
\text { localization }\end{array}$ & $\begin{array}{l}\text { Antibody } \\
\text { independent }\end{array}$ & $\begin{array}{l}\text { Low labeling } \\
\text { efficiency }(\sim 10 \%)\end{array}$ & No & (Nappi et al. 2020) \\
\hline Nitrite sequencing & Oligonucleotides & $\begin{array}{l}\text { Single base } \\
\text { resolution, } \\
\text { antibody } \\
\text { independent }\end{array}$ & $\begin{array}{l}\text { Can only detect } 6 \mathrm{~mA} \\
\text { in a high- } \\
\text { abundance context }\end{array}$ & No & $\begin{array}{l}\text { (Mahdavi-Amiri et al. } \\
\text { 2021) }\end{array}$ \\
\hline
\end{tabular}

lower than previously reported result (Wu et al. 2016). Recently, Fernandes et al. reported that $6 \mathrm{~mA}$ is a ubiquitous eukaryotic epigenetic modification that is put in place during embryogenesis and fetal development (Fernandes et al. 2021). Therefore, more studies are required to determine not only $6 \mathrm{~mA}$ abundance but also how $6 \mathrm{~mA}$ is regulated to confer cellular adaptation in different culture conditions. It is also worth noting that mass spectrometry-based methods cannot detect genomic localization of $6 \mathrm{~mA}$ since the DNA sequence information was lost during hydrolysis step, which makes it challenging to identify possible contamination. Therefore, it is important to apply other independent methods to cross validate the results from mass spectrometrybased methods.

\section{Antibody-based detection methods}

Compared to LC-MS/MS, antibody-based methods are generally less sensitive but much easier to apply. Therefore, antibody-based DNA immunoblotting (Stott 1989) and immunofluorescence staining (Im et al. 2019) are more routinely used for the initial evaluation of $6 \mathrm{~mA}$ levels. Because the current $6 \mathrm{~mA}$ antibody recognizes both RNA $m^{6} \mathrm{~A}$ and DNA $6 \mathrm{~mA}$, it is essential to remove the RNAs prior to the application of antibody-based methods.

Another advantage of the antibody-based method is that the antibody can be used in DNA immunoprecipitation followed by next-generation sequencing (DIP-seq) to specifically enrich methylated DNA fragments and generate genomic profiling of 6mA (Fu et al. 2015; Greer et al. 2015; Zhang et al. 2015; Wu et al. 2016). Similar to histone modification chromatin immunoprecipitation (ChIP-seq), 6mA DIP-seq can only detect $6 \mathrm{~mA}$ sites at a resolution of 100 $500 \mathrm{bp}$. To further increase the resolution of DIP-seq, Fu et al. developed the 6mA-CLIP-exo technique by employing photo-crosslinking followed by exonuclease digestion to achieve a much higher resolution than traditional DIP-seq in Chlamydomonas (Fu et al. 2015). Similar methods were subsequently applied to human genomic and mitochondrial DNA (Koh et al. 2018; Hao et al. 2020).

While antibody-based methods are easy to apply and versatile in detecting global level, subcellular localization, as 
well as genomic localization of $6 \mathrm{~mA}$, the specificity of immunoprecipitation needs to be established in one's experimental system as any other antibody-based epigenetic detection method. The global $6 \mathrm{~mA}$ level has been found as a critical parameter for conventional 6mA DIPseq. A careful "Spike-in" experiments with standard oligonucleotides determined that the threshold for $6 \mathrm{~mA}$ DIP is around $10-15 \mathrm{ppm}$ of $6 \mathrm{~mA}$ in the input samples in order to achieve above 10-fold enrichment over the background signal (Wu et al. 2016). Thus, it is not surprising that majority of $6 \mathrm{~mA}$ DIP signals from human T-cells and other cell lines with ultra-low level of $6 \mathrm{~mA}$ were found that might be nonspecific (Douvlataniotis et al. 2020). A recent study demonstrated that their denaturing DNA $6 \mathrm{~mA}$ IP experiment can effectively enrich $6 \mathrm{~mA}$ modified oligo but not $\mathrm{m}^{6} \mathrm{~A}$ modified DNA-RNA hybrid ( $\mathrm{Li}$ et al. 2020b). Furthermore, the $6 \mathrm{~mA}$ DIP-seq in developing trophoblast stem cells resulted in similar peak pattern against input, IGG, or WGA controls, demonstrating the high specificity of the $6 \mathrm{~mA}$ DIP signal when $6 \mathrm{~mA}$ abundance is above the threshold ( $\mathrm{Li}$ et al. 2020b). Nevertheless, well-controlled experiments, especially the inclusion of proper negative controls, are essential to study $6 \mathrm{~mA}$ with antibody-dependent methods.

\section{Antibody-independent detection methods}

To eliminate the concern of the potential artifacts from $6 \mathrm{~mA}$ antibody, it is crucial for the field to develop antibody independent detection methods to cross-validate the results from antibody-based methods. Here, we summarize the recently developed antibody independent detection methods that may improve our understanding of $6 \mathrm{~mA}$ in mammals.

The first type of antibody-independent $6 \mathrm{~mA}$ detection method is based on digestion with methylation-sensitive restriction enzymes, which specifically cleave methylated or unmethylated DNA. For 6mA, Dpnll (only digests unmethylated GATC), CviAll (only digests unmethylated CATG), and Dpnl (only digests methylated GATC and CATC, preferentially fully methylated) have been used to detect $6 \mathrm{~mA}$ at single-base resolution (Fu et al. 2015; Luo et al. 2016, 2018b). However, this method is limited by the motifs of restriction enzymes, so it is mostly applied in unicellular eukaryotes. As 6mA DIP-seq and SMRT-seq failed to detect these motifs in the mammalian genomes (Wu et al. 2016; Xie et al. 2018; Zhu et al. 2018; Xiao et al. 2018), methylationsensitive restriction enzyme methods are unlikely to be widely used to detect genomic localization of $6 \mathrm{~mA}$ in mammals.

Another antibody-independent method is to directly sequence native DNA using third-generation single-molecule sequencing. Pacific Bioscience's single molecular realtime sequencing (SMRT-seq) detects the $6 \mathrm{~mA}$ by taking advantage of the fact that DNA polymerase kinetics change while replicating modified or unmodified bases (Flusberg et al. 2010). SMRT-seq has been successfully applied to detect $6 \mathrm{~mA}$ in plants and mammals (Wu et al. 2016; Liang et al. 2018; Zhou et al. 2018; Zhu et al. 2018; Xiao et al. 2018). However, the false-positive signal of SMRT-seq in detecting $6 \mathrm{~mA}$ was also discussed (Zhu et al. 2018; Douvlataniotis et al. 2020). Therefore, 6mA enrichment, high sequencing coverage are required to reliably detect $6 \mathrm{~mA}$ using SMRT-seq. It was recently reported that another platform of single-molecule sequencing, Oxford nanopore sequencing, can also detect DNA modifications at singlebase resolution. Nanopore sequencing detects DNA methylation by examining the current difference generated by methylated and unmethylated DNA molecules when going through the sequencing pore (Rand et al. 2017). Computational tools have been developed to detect $6 \mathrm{~mA}$ in prokaryotes and Chlamydomonas from nanopore sequencing data (Stoiber et al. 2016; Rand et al. 2017; Liu et al. 2019; Mclntyre et al. 2019; Ni et al. 2019). However, no such tool was developed for metazoan genomes, largely due to the lack of $6 \mathrm{~mA}$ data at single-base resolution from an accurate method, like bisulfite sequencing for $5 \mathrm{mC}$. While $6 \mathrm{~mA}$ detection from nanopore sequencing is still in the early stage, rapidly developing computational methods in methylation calling and base-calling makes nanopore sequencing a deserving method in detecting $6 \mathrm{~mA}$ in mammals.

Additionally, researchers are also actively developing chemical methods for $6 \mathrm{~mA}$ detection. Hong et al. discovered that $\mathrm{Ag}^{+}$causes primer extension termination at $6 \mathrm{~mA}$ sites but not unmethylated $A$ sites, which can be used to selectively detect $6 \mathrm{~mA}$ (Hong et al. 2016). However, the inability to exponentially amplify DNA fragments made this method difficult for the genome-wide mapping of $6 \mathrm{~mA}$. Alternatively, Nappi et al. reported a method to selectively label $6 \mathrm{~mA}$ by photo-conjugation followed by biotin-ligation (Nappi et al. 2020). This label of $6 \mathrm{~mA}$ can be subsequentially pulled down and cleaved, leaving the enriched $6 \mathrm{~mA}$ fragment that can be quantified by qPCR or sequencing. Nappi et al. further demonstrated that the enrichment by this method is comparable to $6 \mathrm{~mA}$ antibody-based immunoprecipitation. Furthermore, Mahdavi-Amiri et al. reported nitrite sequencing, a method to detect DNA $6 \mathrm{~mA}$ and RNA $\mathrm{m}^{6} \mathrm{~A}$ at single-base resolution (Mahdavi-Amiri et al. 2021). Nitrite sequencing utilizes the sodium nitrite and acetic acid to diazotize and deaminate unmethylated adenine, while methylated adenine cannot complete the deamination. Therefore, unmethylated adenine will be converted to guanine after PCR, while methylated adenine will remain as adenine. By calculating the relative $A$ to $G$ mutation ratio at each base, $6 \mathrm{~mA}$ can be distinguished and quantified at single-base resolution. However, this method requires a high fraction of methylated adenine. Thus, it is challenging to directly apply this method to eukaryotic genome because $6 \mathrm{~mA}$ methylation fraction is likely to be low. On the other hand, since $6 \mathrm{~mA}$ methylation fraction in prokaryotic genome is high enough, this method can be an alternative method for SMRT sequencing to detect $6 \mathrm{~mA}$ at single-base resolution.

Although DNA 6mA detection in the mammalian genomes is challenging due to the low abundance in most adult 
tissues and cell lines, novel detection methods are being rapidly developed. A detection method with high sensitivity, high specificity, and single-base resolution is a bottleneck in $6 \mathrm{~mA}$ 's study. Such a method will greatly move the entire field forward.

\section{THE REGULATION OF 6mA}

The deposition and active removal of epigenetic modifications are mostly catalyzed by enzymes. For example, the canonical methylation on cytosine is catalyzed by DNA methyltransferases (MTase) enzymes (DNMT1, DNMT3A, and DNMT3B), and the demethylation process of $5 \mathrm{mC}$ can be either passive (through cell division) or active (catalyzed by ten-eleven translocation enzymes (TETs)) (Moore et al. 2013). Several studies reported the dynamic regulation of $6 \mathrm{~mA}$ and the putative machinery responsible for the deposition, recognition, and removal of mammalian $6 \mathrm{~mA}(\mathrm{Wu}$ et al. 2016; Xie et al. 2018; Xiao et al. 2018; Kweon et al. 2019; Hao et al. 2020; Li et al. 2020b). The challenging questions in the field are whether the methylation of N6deoxyadenosine in the mammals is catalyzed by MTase, and subsequently, by which MTase.

\section{Putative methyltransferases of $6 \mathrm{~mA}$ in mammals}

Although significant effort has been put into the search for $6 \mathrm{~mA}$ MTases in mammals, the exploration turned out to be challenging due to the low abundance of $6 \mathrm{~mA}$ and the lack of functional model systems to work on. Nevertheless, several groups have identified putative MTases of mammalian $6 \mathrm{~mA}$. Several studies have suggested that N-6 adenine-specific DNA methyltransferase 1 (N6AMT1), the mammalian MTase similar to the prokaryotic DNA 6mA MTase (M. Taql), may mediate the methylation of N6-deoxyadenosine in human liver cancer cells and mouse neurons (Xiao et al. 2018; Li et al. 2019b; Sheng et al. 2021). However, Xie et al. did not observe such activities of N6AMT1 in human glioblastoma (Xie et al. 2018). Additionally, recent structural and biochemical evidence indicated that N6AMT1 could not bind to DNA to catalyze the methylation of $6 \mathrm{~mA}$ ( $\mathrm{Li}$ et al. 2019a).

Another putative MTase of DNA $6 \mathrm{~mA}$ is METTL4. METTL4 is a homologous protein of MTA-70 family eukaryotic MTases in mammals. Its homologs in C. elegans (DAMT1) and T. thermophila (TAMT-1) were identified as the MTase of $6 \mathrm{~mA}$ (Greer et al. 2015; Luo et al. 2018b). Kweon et al. reported that METTL4 catalyzes $6 \mathrm{~mA}$ deposition in genomic DNA of human embryonic kidney cells and mESCs by overexpressing and knocking out METTL4 (Kweon et al. 2019). Consistently, METTL4 has been reported as a $6 \mathrm{~mA}$ MTase during the differentiation of murine 3T3-L1 cells (Zhang et al. 2020b). Furthermore, Hao et al. demonstrated that METTL4 could mediate $6 \mathrm{~mA}$ methylation of mitochondrial DNA (mtDNA) in HepG2 cells and is capable of catalyzing mtDNA $6 \mathrm{~mA}$ methylation under in vitro biochemical conditions (Hao et al. 2020). Of note, exposing HepG2 cells to hypoxia conditions resulted in an upregulation of METTL4 and a corresponding increase in mtDNA 6mA level (Hao et al. 2020). It is worth noting that Woodcock et al. demonstrated that the METTL3-METTL14 complex, a well-known mRNA $m^{6} A$ MTase complex, can also mediate in vitro DNA $6 m A$ methylation on GGACT motif in both single-strand DNA (ssDNA) and unpaired double-strand DNA (dsDNA) oligonucleotides (Woodcock et al. 2019). However, 6mA on such a motif has not been reported in genomic profiling studies (Koziol et al. 2016; Wu et al. 2016; Yao et al. 2017; Xie et al. 2018; Xiao et al. 2018). Further investigations are needed to demonstrate whether the METTL3-METTL14 complex can catalyze DNA methylation in mammalian cells. Nevertheless, METTL4 is currently a promising candidate for the mammalian 6mA MTase (Fig. 1A). The in vitro biochemical evidence of METTL4 as the MTase for $6 \mathrm{~mA}$ in genomic DNA is still lacking, and experiments in multiple different systems are required to validate the DNA MTase activity of METTL4. At the same time, it is crucial to search for additional proteins that may function as DNA 6mA MTase. Moreover, studies to examine the effect of various substrates on the methylation reaction should also be critical.

\section{Other possible sources of physiological $6 \mathrm{~mA}$} in mammals

The low abundance of $6 \mathrm{~mA}$ in mammalian DNA and the lack of definitive DNA $6 \mathrm{~mA}$ MTase mammalian setting raise concerns that $6 \mathrm{~mA}$ may be mis-incorporated by DNA polymerases during DNA replication and DNA damage repair rather than by direct DNA methylation via MTases. A previous report from Charles et al. showed that $6 \mathrm{~mA}$ could be detected in the genomic DNA of $\mathrm{C} 2 \mathrm{C} 12$ cells treated with free $\mathrm{N}^{6}$-Methyl-2'-deoxyadenosine using HPLC-MS/MS but not in untreated cells, indicating that $6 \mathrm{~mA}$ can be incorporated into the mammalian genome (Charles et al. 2004). Musheev et al. showed that while DNA $5 \mathrm{mC}$ are directly mediated by DNA MTase, DNA 6mA may instead originates from ribo- $N^{6}$-methyladenosine degraded from $m^{6} A$ modified RNA and not from direct methylation in 3T3 and C2C12 cells (Fig. 1B) (Musheev et al. 2020). In a separate study, Liu et al. reported that DNA $6 \mathrm{~mA}$ accumulates in the $\mathrm{G}_{1}$ phase and can be incorporated into genomic DNA in mESCs by template-independent polymerase $\lambda$, the major polymerase participating in the non-homologous end joining (NHEJ) DNA repair pathway (Liu et al. 2021). Consistent with the study from Musheev et al., Liu et al. also observed increased genomic $6 \mathrm{~mA}$ level after the treatment of exogenous ribo- $\mathrm{N}^{6}$ methyladenosine, while failing to detect direct methylation activity by possible $6 \mathrm{~mA}$ MTases. These results also suggest that $6 \mathrm{~mA}$ may be incorporated primarily during DNA repair rather than during DNA replication in $\mathrm{mESCs}$. Overall, these studies proposed that the physiological basal level of $6 \mathrm{~mA}$ in normal mammalian cell lines may originate from misincorporation by DNA polymerases. However, Musheev et al. 
A

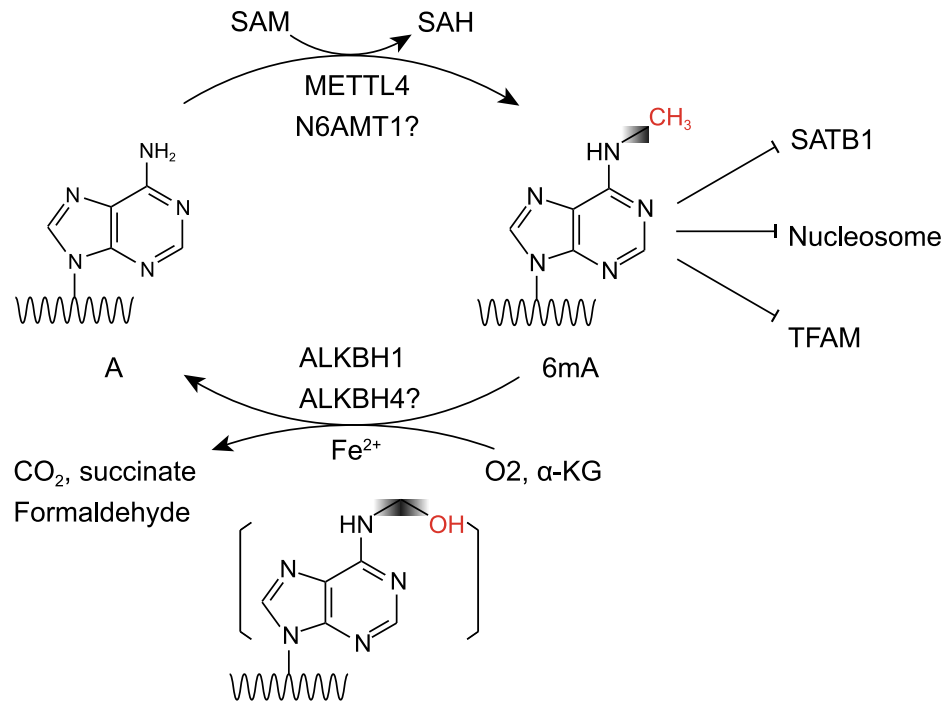

B<smiles>CNc1ncnc2c1ncn2[C@@H]1O[C@H](COP(=O)(O)O)C(O)C1O</smiles>

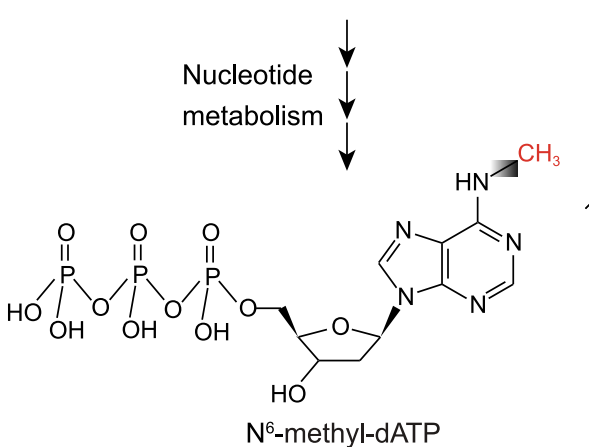<smiles>CNc1ncnc2c1ncn2C</smiles>

Figure 1. Regulation of DNA $6 \mathrm{~mA}$ in the mammalian genome. (A) Methylation and demethylation pathway and biochemical function of $6 \mathrm{~mA}$ in the mammalian DNA. Methyltransferase METTL4 or N6AMT1 catalyze the transfer of methyl group from the methyl donor S-adenosylmethionine (SAM) to unmethylated A, leading to a $6 \mathrm{~mA}$ site and S-adenosylhomocysteine (SAH). $6 \mathrm{~mA}$ can be oxidatively demethylated by ALKBH1 and ALKBH4 using oxygen, alpha-ketoglutarate $(\alpha-K G)$, and ferrous ion $\left(\mathrm{Fe}^{2+}\right)$, leading to an unstable intermediate $6 \mathrm{hmA}$ and rapidly decays to adenine and formaldehyde. $6 \mathrm{~mA}$ has been shown to directly prevent nucleosome, SATB1 and TFAM from binding to DNA. (B) $6 \mathrm{~mA}$ can also be directly incorporated into DNA during DNA replication or DNA damage repair. $\mathrm{N}^{6}$-methyl-dATP can be formed from the $\mathrm{N}^{6}$-methyl-AMP, degraded from methylated RNA, through nucleotide metabolism pathway.

showed that the endogenous level of soluble $6 \mathrm{~mA}$ nucleoside is extremely low or undetectable and in vitro PCR results from Liu et al. revealed that $N^{6}$-methyl-dATP is not the preferred substrate by high fidelity DNA polymerase (Musheev et al. 2020; Liu et al. 2021). Furthermore, it is unclear whether this misincorporation mechanism may account for the high dynamic characteristics of $6 \mathrm{~mA}$ when responding to stress like hypoxia or in pathological conditions (Xie et al. 2018). It is possible that the $6 \mathrm{~mA}$ methyltransferase is only active at specific conditions or in specific niche. Therefore, more evidence is required to either demonstrate or rule out the direct methylation of $6 \mathrm{~mA}$ by DNA MTase. 


\section{The recognition of $6 \mathrm{~mA}$}

To fully understand the biological function of $6 \mathrm{~mA}$ in eukaryotes, it is important to identify proteins that recognize ("read") 6mA. In prokaryotes like E. coli, MutH and SeqA have been reported to recognize and bind the hemi-methylated GATC sites to promote DNA mismatch repair and prevent premature DNA replication (Kramer et al. 1984; Lu et al. 1994). He et al. reported that a Fox-family transcription factor Jumu can bind to $6 \mathrm{~mA}$ modified DNA and negatively regulate the expression of Zelda, a zygotic early Drosophila activator (He et al. 2019). This regulation further controls the proper zygotic genome activation (ZGA), indicating an important role of $6 \mathrm{~mA}$ in Drosophila early embryogenesis. Koh et al. reported that mitochondrial single-stranded DNA binding protein 1 (SSBP1) can be recruited by $6 \mathrm{~mA}$ in HEK293T mitochondria, perhaps due to the dsDNA destabilizing property of $6 \mathrm{~mA}$ (Koh et al. 2018). However, the downstream function of the $6 \mathrm{~mA}$-mediated recruitment of mitochondrial SSBP1 is still unclear. A study by $\mathrm{Hao}$ et al. has revealed that $6 \mathrm{~mA}$ in mtDNA can disrupt the DNA binding of mitochondrial transcription factor $A$ (TFAM) to suppress mtDNA transcription, further demonstrated that $6 \mathrm{~mA}$ plays an important role in the human mitochondrial genome (Fig. 1A). Nevertheless, the proteins that recognize $6 \mathrm{~mA}$ in mammalian nuclear DNA remain elusive. Surprisingly, $\mathrm{Li}$ et al. demonstrated that $6 \mathrm{~mA}$ antagonizes special AT-rich sequence binding protein 1 (SATB1), a crucial chromatin organizer, in stress-induced DNA double helix destabilization (SIDD) regions during the transition from mESCs to trophoblast stem-like cells (TSC) (Fig. 1A). The enrichment of $6 \mathrm{~mA}$ in SIDD regions, in which double-stranded DNA is frequently unpaired, is consistent with structural result that the demethylase ALKBH1 prefers unpairing DNA as substrates (Zhang et al. 2020a; Tian et al. 2020). This antagonizing (anti-reader) effect of $6 \mathrm{~mA}$ on SATB1 binding is supported by both in vitro binding assay and chromatin profiling. Further investigation revealed that this antagonizing effect of $6 \mathrm{~mA}$ on SATB1 modulates the cell fate transition from mESCs to TSCs (Li et al. 2020b). This study provides an alternative mechanism of $6 \mathrm{~mA}$ function by preventing proteins from binding to DNA in mammalian cells. It is still possible that there are other unidentified proteins that can bind to $6 \mathrm{~mA}$ modified DNA in mammalian cells. Further exploration is required to fully understand the recognition machinery or antagonizing effector of $6 \mathrm{~mA}$ and the functional roles in mammalian settings.

\section{The demethylases of $6 \mathrm{~mA}$}

Unlike the determination of $6 \mathrm{~mA}$ methyltransferases in mammals, the search for $6 \mathrm{~mA}$ demethylase has yield significant progress since its report in mESCs. Several studies utilizing genetic and biochemical methods have demonstrated that ALKBH1 can function as the DNA $6 \mathrm{~mA}$ demethylase in the mammalian genome. Structural evidence also supported that ALKBH1 can bind unpairing DNA and catalyze the demethylation of $6 \mathrm{~mA}$ (Zhang et al. 2020a; Tian et al. 2020). ALKBH1 is a homolog of alpha-ketoglutaratedependent dioxygenase (AlkB), which is a bacterial protein responsible for the repair of alkylated DNA and RNA by oxidative demethylation (Falnes et al. 2002). ALKBH1 catalyzes $6 \mathrm{~mA}$ demethylation by hydroxylating the methyl group to a hydroxymethyl group (Zhang et al. 2020a). This unstable hydroxymethyl group can be spontaneously released as formaldehyde, leading to direct demethylation in contrast to the multi-step $5 \mathrm{mC}$ demethylation (Fig. 1A). These enzymatic and structural experiments revealed that ALKBH1 prefers bubbled or bulged DNA instead of conventional single or double-stranded DNA, possibly due to the lack of autonomous base-flipping activity (Zhang et al. 2020a). Consistently, several studies indicate that $6 \mathrm{~mA}$ can modify DNA fine structure by destabilizing the DNA double-strand helix (Diekmann 1987; Koh et al. 2018). Further studies are required to understand more of $A L K B H 1$ in mammals.

In addition to ALKBH1, ALKBH4 has also been reported to function as a demethylase of DNA 6mA (Kweon et al. 2019). ALKBH4 is orthologous to DMAD and NMAD-1, the $6 \mathrm{~mA}$ demethylase identified in $D$. melanogaster and $C$. elegans, respectively (Greer et al. 2015; Zhang et al. 2015; Yao et al. 2018). However, Kweon et al. showed that ALKBH4 primarily demethylate short double-strand oligonucleotides rather than single-strand oligonucleotides, while $6 \mathrm{~mA}$ is predominantly enriched in unpairing regions in mESCs ( $\mathrm{Li}$ et al. 2020b). Yet so far, ALKBH4's role as $6 \mathrm{~mA}$ demethylase has not been reported by other groups. Thus, more studies are required to confirm whether ALKBH4 can demethylate DNA 6mA in multiple systems.

\section{THE BIOLOGICAL FUNCTION OF 6mA IN MAMMALS}

While the critical function of $6 \mathrm{~mA}$ in replication, transcription, and R-M system are well-recognized in prokaryotes, the physiological and pathological roles of $6 \mathrm{~mA}$ in the mammals are still elusive. Particularly, it is still disputable whether the rare $6 \mathrm{~mA}$ in the mammalian genome could play an important biological function. Nevertheless, various emerging evidence supports that $6 \mathrm{~mA}$ can serve as an important modification that responds to different stresses, such as hypoxia (Xie et al. 2018; Hao et al. 2020). In addition, 6mA may be crucial in early development and some pathological conditions, such as cancer and neurological disorders (Yao et al. 2017; Xie et al. 2018; Li et al. 2019b, 2020b).

\section{$6 \mathrm{~mA}$ in early embryonic development}

$6 \mathrm{~mA}$ in the mammalian genome was first identified in mESCs and results in significant transcriptional repression at its deposition sites, especially on young long interspersed nuclear element-1 (LINE1) retrotransposons (Wu et al. 2016). The accumulation of $6 \mathrm{~mA}$ in mESCs results in imbalanced cell fate decisions during in vitro embryoid body 


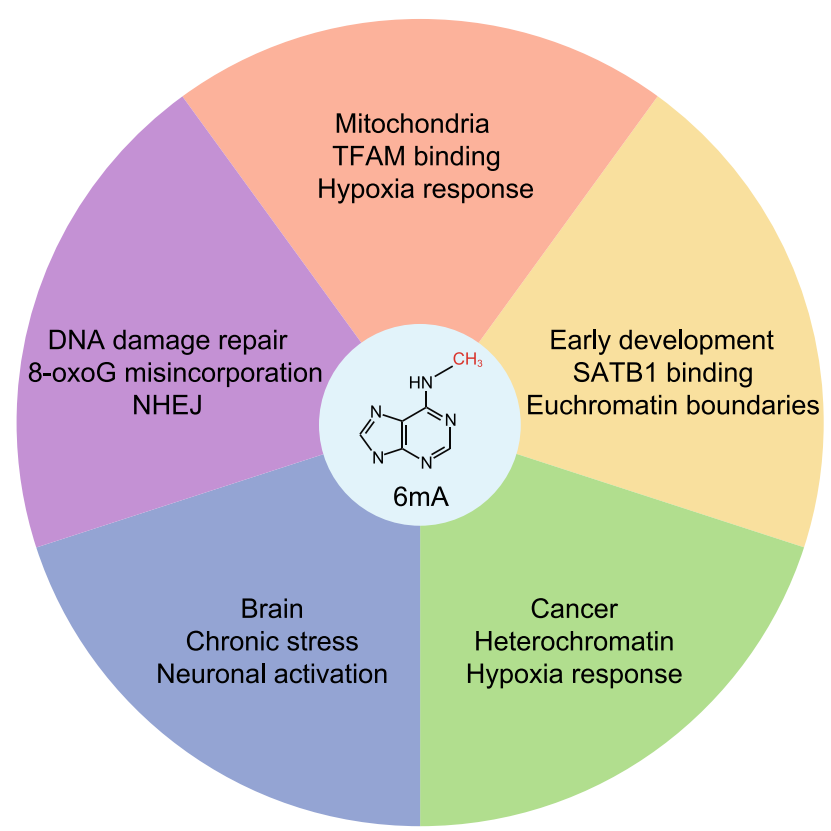

Figure 2. The proposed function of $6 \mathrm{~mA}$ in mammals. $6 \mathrm{~mA}$ has been reported to play important roles in mammals, such as mitochondrial activity, early development, tumorigenesis, brain function, and DNA damage repair.

differentiation by regulating the expression of key developmental genes such as Nanog, Cdx2, Lefty1\&2, and Foxa2 (Wu et al. 2016). Consistently, 6mA was found to be dynamically regulated during early embryogenesis in zebrafish and pigs (Liu et al. 2016). However, whether 6mA plays a direct role in early embryo development was unclear. $A$ recent study suggested that $6 \mathrm{~mA}$ plays a key role in placenta development ( $\mathrm{Li}$ et al. 2020b). Concretely, Li et al. found that a high level of $6 \mathrm{~mA}$ is present in cells transitioning from mESCs to mouse trophoblast stem (TS)-like cells. Genomic profiling revealed that $6 \mathrm{~mA}$ is enriched at regions of SIDD, and $6 \mathrm{~mA}$ deposition was found to function at euchromatin boundaries to restrict the spread of euchromatin by preventing SATB1 chromatin association. Additionally, 6mA-SATB1 antagonism was reported to be essential for trophoblast development in both the cell line and mouse model. This work is the first to demonstrate that $6 \mathrm{~mA}$ may play an essential role in murine early development. More research is needed to investigate whether $6 \mathrm{~mA}$ has a similar role in other organisms.

\section{$6 \mathrm{~mA}$ in brain}

In addition to its function in early development, many efforts have been made to investigate the role of $6 \mathrm{~mA}$ in the mammalian brain. Yao and colleagues discovered that the $6 \mathrm{~mA}$ level in the prefrontal cortex (PFC) was increased from $6.6 \mathrm{ppm}$ to $25.5 \mathrm{ppm}$ in mice exposed to chronic stress (Yao et al. 2017). Consistent with the genomic distribution of $6 \mathrm{~mA}$ in mESCs, genomic profiling indicated that increased $6 \mathrm{~mA}$ by chronic stress were enriched at repetitive elements like LINE1. Additionally, transcriptomic profiling showed $6 \mathrm{~mA}$ negatively correlates with the expression of LINE retrotransposons and a group of neuronal genes. Similarly, another study demonstrated $6 \mathrm{~mA}$ accumulated in primary cortical neurons after neuronal activity was induced in vitro ( $\mathrm{Li}$ et al. 2019b). The study also investigated 6mA levels in neurons that can be selectively activated by fear extinction learning in the infralimbic prefrontal cortex (ILPFC) of adult mice. However, Dpnl-seq identified a surprisingly large number of $6 \mathrm{~mA}$ sites (more than two million sites), which was far more abundant than the estimated level by the DIP-seq method in PFC (Yao et al. 2017). It is possible that such a difference was observed due to different contexts, stress types, or detection methods. It would be interesting to see whether this high level of $6 \mathrm{~mA}$ can be verified by LC-MS/MS. Overall, these studies suggest that $6 \mathrm{~mA}$ has an important function in the mammalian brain, especially PFC. An important question is whether $6 \mathrm{~mA}$ plays a role in pathological conditions, such as neurological diseases.

\section{$6 \mathrm{~mA}$ in cancer}

DNA methylation is not only essential for early mammalian development but also crucial for tumorigenesis (Kulis and Esteller 2010). While the critical role of $5 \mathrm{mC}$ in regulating transcription during cancer development is well recognized, how other types of DNA modifications like $6 \mathrm{~mA}$ may contribute to tumorigenesis remains elusive. Xie et al. reported that $6 \mathrm{~mA}$ is highly upregulated and a potential therapeutic target in human glioblastoma (Xie et al. 2018). Genomic profiling showed that $6 \mathrm{~mA}$ is co-localized with heterochromatic histone modifications, predominantly $\mathrm{H} 3 \mathrm{~K} 9 \mathrm{me} 3$ in glioblastoma stem cells (GSCs). To investigate the function of $6 \mathrm{~mA}$ in glioblastoma, Xie et al. knocked-down ALKBH1, the demethylase of $6 \mathrm{~mA}$, and observed an increase in $6 \mathrm{~mA}$ and $\mathrm{H} 3 \mathrm{~K} 9 \mathrm{me} 3$ level as well as an inhibition in GSC growth. Further analysis showed that ALKBH1-sensitive $6 \mathrm{~mA}$ are significantly enriched in and regulating key oncogenic pathways, including the hypoxia response pathway. Consistently, $6 \mathrm{~mA}$ was reported to be elevated in human esophageal squamous cell carcinoma (Chen et al. 2020). In contrast, studies have reported a decrease of DNA $6 \mathrm{~mA}$ level in primary gastric, liver, and lung cancers (Liang et al. 2016; Xiao et al. 2018). It is possible that the expression, regulation, and function of $6 \mathrm{~mA}$ vary in different types of cancer. Further investigations are required to elucidate the regulatory mechanism and functional role of $6 \mathrm{~mA}$ in cancer.

\section{$6 \mathrm{~mA}$ in mitochondria}

The endosymbiotic hypothesis for the origin of mitochondria suggests that mitochondria are descended from specialized prokaryotes, a concept supported by the similarity of 
mitochondrial DNA (mtDNA) and bacterial genome (Gray 2012). Whether mtDNA preserves high levels of $6 \mathrm{~mA}$ like bacteria and the function of $6 \mathrm{~mA}$ in mtDNA have attracted much attention in the field. Several publications detected a higher level of $6 \mathrm{~mA}$ in $\mathrm{mtDNA}$ than in nuclear DNA via different detection methods (Koh et al. 2018; Xiao et al. 2018; Hao et al. 2020). Koh et al. first systematically investigated mitochondrial $6 \mathrm{~mA}$ in HEK293T cells. Their UHPLC-MS/MS data showed a significantly higher level of $6 \mathrm{~mA}$ in $\mathrm{mtDNA}$ $(\sim 18 \mathrm{ppm})$ compared to genomic DNA (<1 ppm). Functionally, Koh et al. observed a decrease in mitochondrial oxidative phosphorylation after knocking-out ALKBH1, the demethylase of $6 \mathrm{~mA}$. Similarly, Hao et al. investigated the level of mitochondrial $6 \mathrm{~mA}$ in multiple cell or tissue types, including HepG2 cells, 143B cells, MDA-MB-231 cells, mouse primary fibroblast cells, testes, and spleens. Their UHPLC-MS/MS results showed significant enrichment of $6 \mathrm{~mA}$ in mtDNA in all samples tested, especially in HepG2 cells (up to $400 \mathrm{ppm}$ in mtDNA). Additionally, they identified the co-localization of a potential MTase (METTL4) and mitochondria in HepG2 cells. Consistent with the previous study, Hao et al. observed an elevated protein level of the OXPHOS complex III component upon METTL4 knockdown. Furthermore, Hao et al. demonstrated $6 \mathrm{~mA}$ suppresses mitochondria gene transcription by preventing TFAM from binding to DNA. Finally, Hao et al. found that hypoxia can further elevate $6 \mathrm{~mA}$ in $\mathrm{mtDNA}$, indicating mitochondrial $6 \mathrm{~mA}$ may play an important role in regulating the hypoxia stress response. Together, these studies demonstrated a significant enrichment of $6 \mathrm{~mA}$ in mtDNA compared to nuclear DNA, and that $6 \mathrm{~mA}$ in mtDNA plays a crucial role in regulating mitochondria activity and responding to environmental stress like hypoxia. It will be interesting to test whether there is crosstalk between mitochondria $6 \mathrm{~mA}$ and the nuclear epigenetic regulation.

\section{$6 \mathrm{~mA}$ in DNA damage repair}

While the role of $6 \mathrm{~mA}$ in DNA mismatch repair is wellestablished in prokaryotes, it is still unclear whether this role of $6 \mathrm{~mA}$ is conserved in eukaryotes. Zhang et al. have proposed an elegant model that DNA $6 \mathrm{~mA}$ at nucleotide excision repair (NER) sites may prevent the misincorporation of 8-oxoguanine (8-oxoG), as the misincorporation of 8-oxoG into DNA opposite to unmethylated adenine will lead to a transversion mutation from T:A to G:C (Zhang et al. 2021). Thus, DNA 6mA may function as a protective DNA modification to prevent the transversion from T:A to $G: C$. One concern of this model is that majority of single-stranded adenine sites after nucleotide excision need to be methylated to efficiently prevent misincorporation of 8-oxoG. Given the replication error rate $(\sim 1$ in 100,000$)$ and the average length of single-stranded DNA gap during NER ( 25-30 nt), the abundance of $6 \mathrm{~mA}$ need to be around 62.5 to $75 \mathrm{ppm}$ to prevent the incorporation of 8-oxoG, which is at least one order of magnitude higher than previously reported basal level of $6 \mathrm{~mA}$ in many cell lines ( 0.1-7 ppm). Nevertheless, the model may hold true in more specific conditions, such as the repair of UV-induced DNA damage and double strand breaks.

In another study, Liu et al. reported that $6 \mathrm{~mA}$ is accumulated at the $G_{1}$ phase and polymerase lambda $(p o l \lambda)$ can directly incorporate $6 \mathrm{~mA}$ into DNA in mESCs, indicating that $6 \mathrm{~mA}$ may also play a role in NHEJ pathway (Fig. 1B, 2) (Liu et al. 2021). However, the exact role of $6 \mathrm{~mA}$ in the NHEJ pathway remains unknown. Further investigation is required to better understand the function of $6 \mathrm{~mA}$ in DNA damage repair.

Collectively, although $6 \mathrm{~mA}$ has been identified in various eukaryotic species, the functional research of $6 \mathrm{~mA}$ in these species is still in the initial stage. Many of the studies showed that $6 \mathrm{~mA}$ is more dynamically regulated, compared to $5 \mathrm{mC}$, by different environmental stress, including hypoxia (Xie et al. 2018; Hao et al. 2020), chronic stress (Yao et al. 2017), extinction learning (Li et al. 2019b), and mitochondrial stress (Ma et al. 2019). These discoveries indicate that $6 \mathrm{~mA}$ can serve as an epigenetic mark that quickly responds to different environmental stresses and protects cells from more severe consequences. Further studies are required to investigate the detailed mechanisms of how these environmental stresses induce the upregulation of $6 \mathrm{~mA}$. Moreover, these conditions should be utilized to help identify the possible methyltransferases or readers of $6 \mathrm{~mA}$ in different functional models.

\section{CONCLUSION AND OUTLOOK}

DNA 6mA has been identified in many eukaryotic species in recent years (Fu et al. 2015; Greer et al. 2015; Zhang et al. 2015; Wu et al. 2016; Xiao et al. 2018). Functionally, $6 \mathrm{~mA}$ has been shown to play critical roles in regulating gene expression, retrotransposon suppression, stress response, chromatin organization, tumorigenesis, and early embryonic development (Wu et al. 2016; Yao et al. 2017; Xie et al. 2018; Li et al. 2020b). Research on the regulation of $6 \mathrm{~mA}$ in the mammalian genome is still in the early stage. Whether the origin of $6 \mathrm{~mA}$ in the mammalian genome are through DNA MTases like METTL4 or from misincorporation of methylated bases by DNA polymerases remains elusive (Kweon et al. 2019; Hao et al. 2020; Musheev et al. 2020; Liu et al. 2021). The removal of $6 \mathrm{~mA}$ is mediated by demethylases like ALKBH1 and ALKBH4 (Wu et al. 2016; Kweon et al. 2019). While $6 \mathrm{~mA}$ has been shown to prevent DNA binding of nucleosome and proteins (SATB1 and TFAM) (Luo et al. 2018b; Beh et al. 2019; Hao et al. 2020; Li et al. $2020 \mathrm{~b})$, the existence of "reader" proteins that specifically recognize and bind $6 \mathrm{~mA}$ sites in mammals is still an open question. Thus, additional research into the mechanism pathways of deposition, removal, and recognition of $6 \mathrm{~mA}$ in mammals is crucial to further understand its function. Particularly, deciphering the methyltransferase of $6 \mathrm{~mA}$ in mammalian settings remains the major challenge. 
Another major challenge for the research on $6 \mathrm{~mA}$ is the lack of methods to efficiently map $6 \mathrm{~mA}$ at single-base resolution via currently available strategies. We believe that with the advances in chemical and third-generation sequencing methods, there will soon be breakthroughs in the methodology of $6 \mathrm{~mA}$ detection. These novel methods will greatly help researchers better characterize the function of $6 \mathrm{~mA}$ in the mammals.

The last but not least, $6 \mathrm{~mA}$ functional roles should be explored in the specific model systems and the right "niche".

\section{ACKNOWLEDGMENTS}

We thank Dr. Andrew Z. Xiao of the Yale University and Dr. Hongjie $\mathrm{Li}$ of Baylor College of Medicine for comments on the manuscript. Tao P. Wu is a CPRIT scholar for cancer research. This work is supported by grants from CPRIT (RR180072) and Rivkin Center Scientific Scholar Award.

\section{ABBREVIATIONS}

$5 \mathrm{mC}, 5$-methylcytosine; $6 \mathrm{~mA}, \mathrm{~N}^{6}$-methyladenine; 4mC, N4-methylcytosine; 5hmC, 5-hydroxymethylcytosine; 5fC, 5-formylcytosine; 5caC, 5-carboxylcytosine; AlkB, alpha-ketoglutarate-dependent dioxygenase; DIP-seq, DNA immunoprecipitation followed by sequencing; GSCs, glioblastoma stem cells; $\mathrm{m}^{6} \mathrm{~A}, \mathrm{~N}^{6}$-methyladenosine; $\mathrm{m}^{6} \mathrm{dA}, \mathrm{N}^{6}$-methyldeoxyadenosine; mESCs, mouse embryonic stem cells; MTase, methyltransferase; mtDNA, mitochondrial DNA; N6AMT1, N-6 adenine-specific DNA methyltransferase 1; REase, restriction endonuclease; SATB1, special AT-rich sequence binding protein 1; SIDD, stress-induced DNA double helix destabilization; SMRT-seq, single molecular real-time sequencing; SSBP1, single stranded DNA binding protein 1; TETs, ten-eleven translocation enzymes; TFAM, mitochondrial transcription factor A; TSC, trophoblast stem-like cells; UHPLC-MS/MS, ultra-high-performance liquid chromatography coupled with a triple-quadrupole tandem mass spectrometry; ZGA, zygotic genome activation.

\section{COMPLIANCE WITH ETHICS GUIDELINES}

Xuwen Li, Zijian Zhang, Xinlong Luo, Jacob Schrier, Andrew D. Yang, and Tao P. Wu declare that they have no conflict of interest. This article does not contain any studies with human or animal subjects performed by the any of the authors.

\section{OPEN ACCESS}

This article is licensed under a Creative Commons Attribution 4.0 International License, which permits use, sharing, adaptation, distribution and reproduction in any medium or format, as long as you give appropriate credit to the original author(s) and the source, provide a link to the Creative Commons licence, and indicate if changes were made. The images or other third party material in this article are included in the article's Creative Commons licence, unless indicated otherwise in a credit line to the material. If material is not included in the article's Creative Commons licence and your intended use is not permitted by statutory regulation or exceeds the permitted use, you will need to obtain permission directly from the copyright holder. To view a copy of this licence, visit http:// creativecommons.org/licenses/by/4.0/.

\section{REFERENCES}

Abakir A, Giles TC, Cristini A, Foster JM, Dai N, Starczak M, RubioRoldan A, Li M, Eleftheriou M, Crutchley J et al (2020) N 6-methyladenosine regulates the stability of RNA:DNA hybrids in human cells. Nat Genet 52:48-55

Beh LY, Debelouchina GT, Clay DM, Thompson RE, Lindblad KA, Hutton ER, Bracht JR, Sebra RP, Muir TW, Landweber LF (2019) Identification of a DNA N6-adenine methyltransferase complex and its impact on chromatin organization. Cell 177:1781-1796

Boyer HW (1971) DNA restriction and modification mechanisms in bacteria. Annu Rev Microbiol 25:153-176

Bromberg S, Pratt K, Hattman S (1982) Sequence specificity of DNA adenine methylase in the protozoan Tetrahymena thermophila. J Bacteriol 150:993-996

Charles MP, Ravanat JL, Adamski D, D’Orazi G, Cadet J, Favier A, Berger F, Wion D (2004) N6-methyldeoxyadenosine, a nucleoside commonly found in prokaryotes, induces $\mathrm{C} 2 \mathrm{C} 12$ myogenic differentiation. Biochem Biophys Res Commun 314:476-482

Chen L, Zhang M, Guo M (2020) DNA N6-methyladenine epigenetic modification elevated in human esophageal squamous cell carcinoma: a potential prognostic marker. Discov Med 157:85-90

Diekmann S (1987) DNA methylation can enhance or induce DNA curvature. EMBO J 6:4213-4217

Douvlataniotis K, Bensberg M, Lentini A, Gylemo B, Nestor CE (2020) No evidence for DNA N6-methyladenine in mammals. Sci Adv 6:eaay3335

Dunn DB, Smith JD (1955) Occurrence of a new base in the deoxyribonucleic acid of a strain of Bacterium coli. Nature 175:336-337

Dunn DB, Smith JD (1958) The occurrence of 6-methylaminopurine in deoxyribonucleic acids. Biochem J 68:627-636

Falnes P, Johansen RF, Seeberg E (2002) AlkB-mediated oxidative demethylation reverses DNA damage in Escherichia coli. Nature 419:178-182

Fernandes SB, Grova N, Roth S, Duca RC, Godderis L, Guebels P, Mériaux SB, Lumley Al, Bouillaud-Kremarik P, Ernens I et al (2021) N6-methyladenine in eukaryotic DNA: tissue distribution, early embryo development, and neuronal toxicity. Front Genet 12:696

Flusberg BA, Webster DR, Lee JH, Travers KJ, Olivares EC, Clark TA, Korlach J, Turner SW (2010) Direct detection of DNA methylation during single-molecule, real-time sequencing. Nat Methods 7:461-465

Fu Y, Luo GZ, Chen K, Deng X, Yu M, Han D, Hao Z, Liu J, Lu X, Doré LC et al (2015) N6-methyldeoxyadenosine marks active transcription start sites in Chlamydomonas. Cell 161:879-892

Gorovsky MA, Hattman S, Pleger GL (1973) [6N]methyl adenine in the nuclear DNA of a eucaryote, Tetrahymena Pyriformis. J Cell Biol 56:697-701

Gray MW (2012) Mitochondrial evolution. Cold Spring Harb Perspect Biol 4:a011403 
Greer EL, Blanco MA, Gu L, Sendinc E, Liu J, Aristizábal-Corrales D, Hsu CH, Aravind L, He C, Shi Y (2015) DNA methylation on N6adenine in C. elegans. Cell 161:868-878

Hao Z, Wu T, Cui X, Zhu P, Tan C, Dou X, Hsu KW, Te LY, Peng PH, Zhang LS et al (2020) N6-deoxyadenosine methylation in mammalian mitochondrial DNA. Mol Cell 78:382-395

He S, Zhang G, Wang J, Gao Y, Sun R, Cao Z, Chen Z, Zheng X, Yuan J, Luo Y et al (2019) 6mA-DNA-binding factor Jumu controls maternal-to-zygotic transition upstream of Zelda. Nat Commun 10:1-14

Hong T, Yuan Y, Wang T, Ma J, Yao Q, Hua X, Xia Y, Zhou X (2016) Selective detection of N6-methyladenine in DNA via metal ionmediated replication and rolling circle amplification. Chem Sci 8:200-205

Huang W, Xiong J, Yang Y, Liu SM, Yuan BF, Feng YQ (2015) Determination of DNA adenine methylation in genomes of mammals and plants by liquid chromatography/mass spectrometry. RSC Adv 5:64046-64054

Im K, Mareninov S, Diaz MFP, Yong WH (2019) An introduction to performing immunofluorescence staining. Methods Mol Biol 1897:299-311

Koh CWQ, Goh YT, Toh JDW, Neo SP, Ng SB, Gunaratne J, Gao YG, Quake SR, Burkholder WF, Goh WSS (2018) Singlenucleotide-resolution sequencing of human N6-methyldeoxyadenosine reveals strand-asymmetric clusters associated with SSBP1 on the mitochondrial genome. Nucleic Acids Res 46:11659-11670

Koziol MJ, Bradshaw CR, Allen GE, Costa ASH, Frezza C, Gurdon JB (2016) Identification of methylated deoxyadenosines in vertebrates reveals diversity in DNA modifications. Nat Struct Mol Biol 23:24-30

Kramer B, Kramer W, Fritz HJ (1984) Different base/base mismatches are corrected with different efficiencies by the methyldirected DNA mismatch-repair system of $E$. coli. Cell 38:879-887

Kulis M, Esteller M (2010) DNA methylation and cancer. Adv Genet 70:27-56

Kweon SM, Chen Y, Moon E, Kvederaviciutè K, Klimasauskas S, Feldman DE (2019) An adversarial DNA N6-methyladeninesensor network preserves polycomb silencing. Mol Cell 74:11381147

Li E, Zhang Y (2014) DNA methylation in mammals. Cold Spring Harb Perspect Biol 6:a019133

Li W, Shi Y, Zhang T, Ye J, Ding J (2019a) Structural insight into human N6amt1-Trm112 complex functioning as a protein methyltransferase. Cell Discov 5:1-13

Li X, Zhao Q, Wei W, Lin Q, Magnan C, Emami MR, Wearick-Silva LE, Viola TW, Marshall PR, Yin J et al (2019b) The DNA modification N6-methyl-2'-deoxyadenosine (m6dA) drives activity-induced gene expression and is required for fear extinction. Nat Neurosci 22:534-544

Li H, Wu Z, Liu X, Zhang S, Ji Q, Jiang X, Liu Z, Wang S, Qu J, Zhang $W$ et al (2020a) ALKBH1 deficiency leads to loss of homeostasis in human diploid somatic cells. Protein Cell 11:688695

Li Z, Zhao S, Nelakanti RV, Lin K, Wu TP, Alderman MH, Guo C, Wang P, Zhang M, Min W et al (2020b) N6-methyladenine in DNA antagonizes SATB1 in early development. Nature 583:625-630
Liang D, Wang H, Song W, Xiong X, Zhang X, Hu Z, Guo H, Yang Z, Zhai S, Zhang LH et al (2016) The decreased N6-methyladenine DNA modification in cancer cells. Biochem Biophys Res Commun 480:120-125

Liang Z, Shen L, Cui X, Bao S, Geng Y, Yu G, Liang F, Xie S, Lu T, Gu $X$ et al (2018) DNA N6-adenine methylation in Arabidopsis thaliana. Dev Cell 45:406-416

Liu J, Zhu Y, Luo GZ, Wang X, Yue Y, Wang X, Zong X, Chen K, Yin $\mathrm{H}$, Fu $\mathrm{Y}$ et al (2016) Abundant DNA 6mA methylation during early embryogenesis of zebrafish and pig. Nat Commun 7:13052

Liu B, Liu X, Lai W, Wang H (2017) Metabolically generated stable isotope-labeled deoxynucleoside code for tracing DNA N6methyladenine in human cells. Anal Chem 89:6202-6209

Liu Q, Fang L, Yu G, Wang D, Le XC, Wang K (2019) Detection of DNA base modifications by deep recurrent neural network on Oxford Nanopore sequencing data. Nat Commun 10:2449

Liu X, Lai W, Li Y, Chen S, Liu B, Zhang N, Mo J, Lyu C, Zheng J, Du YR et al (2021) N6-methyladenine is incorporated into mammalian genome by DNA polymerase. Cell Res 31:94-97

Lu M, Campbell JL, Boye E, Kleckner N (1994) SeqA: a negative modulator of replication initiation in E. coli. Cell 77:413-426

Luo GZ, Wang F, Weng X, Chen K, Hao Z, Yu M, Deng X, Liu J, He C (2016) Characterization of eukaryotic DNA N6-methyladenine by a highly sensitive restriction enzyme-assisted sequencing. Nat Commun 7:11301

Luo C, Hajkova P, Ecker JR (2018a) Dynamic DNA methylation: in the right place at the right time. Science 361:1336-1340

Luo GZ, Hao Z, Luo L, Shen M, Sparvoli D, Zheng Y, Zhang Z, Weng $X$, Chen K, Cui Q et al (2018b) N6-methyldeoxyadenosine directs nucleosome positioning in Tetrahymena DNA 06 biological sciences 0604 genetics. Genome Biol 19:200

Ma C, Niu R, Huang T, Shao LW, Peng Y, Ding W, Wang Y, Jia G, He C, Li CY et al (2019) N6-methyldeoxyadenine is a transgenerational epigenetic signal for mitochondrial stress adaptation. Nat Cell Biol 21:319-327

Mahdavi-Amiri Y, Chung Kim Chung K, Hili R (2021) Singlenucleotide resolution of: N6-adenine methylation sites in DNA and RNA by nitrite sequencing. Chem Sci 12:606-612

Marinus MG, Morris NR (1973) Isolation of deoxyribonucleic acid methylase mutants of Escherichia coli $\mathrm{K}-12$. J Bacteriol 114:1143-1150

Marinus MG, Morris NR (1974) Biological function for 6-methyladenine residues in the DNA of Escherichia coli K12. J Mol Biol 85:309-322

Mclntyre ABR, Alexander N, Grigorev K, Bezdan D, Sichtig H, Chiu CY, Mason CE (2019) Single-molecule sequencing detection of N6-methyladenine in microbial reference materials. Nat Commun 10:579

Moore LD, Le T, Fan G (2013) DNA methylation and its basic function. Neuropsychopharmacology 38:23-38

Musheev MU, Baumgärtner A, Krebs L, Niehrs C (2020) The origin of genomic N 6-methyl-deoxyadenosine in mammalian cells. Nat Chem Biol 16:630-634

Nappi M, Hofer A, Balasubramanian S, Gaunt MJ (2020) Selective chemical functionalization at N6-methyladenosine residues in dna enabled by visible-light-mediated photoredox catalysis. J Am Chem Soc 142:21484-21492 
Ni P, Huang N, Zhang Z, Wang DP, Liang F, Miao Y, Le XC, Luo F, Wang J (2019) DeepSignal: detecting DNA methylation state from Nanopore sequencing reads using deep-learning. Bioinformatics 35:4586-4595

O'Brown ZK, Boulias K, Wang J, Wang SY, O'Brown NM, Hao Z, Shibuya H, Fady PE, Shi Y, He C et al (2019) Sources of artifact in measurements of $6 \mathrm{~mA}$ and $4 \mathrm{mC}$ abundance in eukaryotic genomic DNA. BMC Genomics 20:445

Rand AC, Jain M, Eizenga JM, Musselman-Brown A, Olsen HE, Akeson M, Paten B (2017) Mapping DNA methylation with highthroughput nanopore sequencing. Nat Methods 14:411-413

Ratel D, Ravanat JL, Charles MP, Platet N, Breuillaud L, Lunardi J, Berger F, Wion D (2006) Undetectable levels of N6-methyl adenine in mouse DNA: cloning and analysis of PRED28, a gene coding for a putative mammalian DNA adenine methyltransferase. FEBS Lett 580:3179-3184

Robbins-Manke JL, Zdraveski ZZ, Marinus M, Essigmann JM (2005) Analysis of global gene expression and double-strand-break formation in DNA adenine methyltransferase- and mismatch repair-deficient Escherichia coli. J Bacteriol 187:7027-7037

Sánchez-Romero MA, Cota I, Casadesús J (2015) DNA methylation in bacteria: from the methyl group to the methylome. Curr Opin Microbiol 25:9-16

Schiffers S, Ebert C, Rahimoff R, Kosmatchev O, Steinbacher J, Bohne AV, Spada F, Michalakis S, Nickelsen J, Müller M et al (2017) Quantitative LC-MS provides no evidence for m6dA or $\mathrm{m} 4 \mathrm{dC}$ in the genome of mouse embryonic stem cells and tissues. Angew Chem Int Ed 56:11268-11271

Schübeler D (2015) Function and information content of DNA methylation. Nature 517:321-326

Sheng X, Wang J, Guo Y, Zhang J, Luo J (2021) DNA N6methyladenine $(6 \mathrm{~mA})$ modification regulates drug resistance in triple negative breast cancer. Front Oncol 10:616098

Smith ZD, Meissner A (2013) DNA methylation: roles in mammalian development. Nat Rev Genet 14:204-220

Smith JD, Arber W, Kühnlein U (1972) Host specificity of DNA produced by Escherichia coli. XIV. the role of nucleotide methylation in in vivo B-specific modification. J Mol Biol 63:1-8

Sternberg N (1985) Evidence that adenine methylation influences DNA-protein interactions in Escherichia coli. J Bacteriol 164:490493

Stoiber M, Quick J, Egan R, Eun Lee J, Celniker S, Neely R, Loman N, Pennacchio L, Brown J (2016) De novo identification of DNA modifications enabled by genome-guided nanopore signal processing. bioRxiv. https://doi.org/10.1101/094672

Stott DI (1989) Immunoblotting and dot blotting. J Immunol Methods 119:153-187

Tian L-F, Liu Y-P, Chen L, Tang Q, Wu W, Sun W, Chen Z, Yan X-X (2020) Structural basis of nucleic acid recognition and $6 \mathrm{~mA}$ demethylation by human ALKBH1. Cell Res 30:272-275
Vanyushin BF, Belozersky AN, Kokurina NA, Kadirova DX (1968) 5-methylcytosine and 6-methylaminopurine in bacterial DNA. Nature 218:1066-1067

Wetzel C, Limbach PA (2016) Mass spectrometry of modified RNAs: recent developments. Analyst 141:16-23

Woodcock CB, Yu D, Hajian T, Li J, Huang Y, Dai N, Corrêa IR, Wu T, Vedadi M, Zhang $X$ et al (2019) Human MettL3-MettL14 complex is a sequence-specific DNA adenine methyltransferase active on single-strand and unpaired DNA in vitro. Cell Discov 5:63

Wu TP, Wang T, Seetin MG, Lai Y, Zhu S, Lin K, Liu Y, Byrum SD, Mackintosh SG, Zhong M et al (2016) DNA methylation on N6adenine in mammalian embryonic stem cells. Nature 532:329333

Xiao CL, Zhu S, He M, Chen D, Zhang Q, Chen Y, Yu G, Liu J, Xie $S Q$, Luo F et al (2018) N6-methyladenine DNA modification in the human genome. Mol Cell 71:306-318

Xie Q, Wu TP, Gimple RC, Li Z, Prager BC, Wu Q, Yu Y, Wang P, Wang Y, Gorkin DU et al (2018) N6-methyladenine DNA modification in glioblastoma. Cell 175:1228-1243

Yao B, Cheng Y, Wang Z, Li Y, Chen L, Huang L, Zhang W, Chen D, $\mathrm{Wu} \mathrm{H}$, Tang B et al (2017) DNA N6-methyladenine is dynamically regulated in the mouse brain following environmental stress. Nat Commun 8:1122

Yao B, Li Y, Wang Z, Chen L, Poidevin M, Zhang C, Lin L, Wang F, Bao $\mathrm{H}$, Jiao B et al (2018) Active N6-methyladenine demethylation by DMAD regulates gene expression by coordinating with polycomb protein in neurons. Mol Cell 71:848-857

Zhang G, Huang H, Liu D, Cheng Y, Liu X, Zhang W, Yin R, Zhang D, Zhang P, Liu J et al (2015) N6-methyladenine DNA modification in Drosophila. Cell 161:893-906

Zhang M, Yang S, Nelakanti R, Zhao W, Liu G, Li Z, Liu X, Wu T, Xiao A, Li H (2020a) Mammalian ALKBH1 serves as an N6-mA demethylase of unpairing DNA. Cell Res 30:197-210

Zhang Z, Hou Y, Wang Y, Gao T, Ma Z, Yang Y, Zhang P, Yi F, Zhan $J$, Zhang $\mathrm{H}$ et al (2020b) Regulation of adipocyte differentiation by METTL4, a 6 mA methylase. Sci Rep 10:8285

Zhang X, Blumenthal RM, Cheng X (2021) A role for N6-methyladenine in DNA damage repair. Trends Biochem Sci 46:175-183

Zhou C, Wang C, Liu H, Zhou Q, Liu Q, Guo Y, Peng T, Song J, Zhang J, Chen L et al (2018) Identification and analysis of adenine N6-methylation sites in the rice genome. Nat Plants 4:554-563

Zhu S, Beaulaurier J, Deikus G, Wu TP, Strahl M, Hao Z, Luo G, Gregory JA, Chess A, He C et al (2018) Mapping and characterizing N6-methyladenine in eukaryotic genomes using singlemolecule real-time sequencing. Genome Res 28:1067-1078 